\title{
Field Efficiency of some New Insecticides Against some Sucking Insects at Cucumber Plants
}

\author{
Ahmed A. Barrania ${ }^{1}$ Mabrok A. El-Bessomy ${ }^{1}$ and Atef T. El-Masry ${ }^{1}$
}

\begin{abstract}
The efficiency of some new insecticides, (sulfoxaflor and flupyradifurone) were compared with three neonicotinoid insecticides (clothianidin, thiamethoxam and acetamiprid), at recommended rates, against Bemisia tabaci, Aphis gossypii and their parasitoid on cucumber plants, during 2017 and 2018 summer seasons at Nubarya district, El-Beheira Governorate. Results showed that, sulfoxaflor and flupyradifurone exhibited excellent and fast action activity against $B$. tabaci and $A$. gossypii, and the least reduction percentages were recorded by acetamiprid at both seasons. Under the same conditions, three neonicotinoid insecticides had moderate toxic effect against natural enemies; Chrysoperla carnea and Coccinella spp, while, sulfoxaflor and flupyradifurone had slightly toxic effect. The present study suggests the use of sulfoxaflor and flupyradifurone are preferred insecticides, with less harmful effects on the fitness components of natural enemies, for integrated pest management of sucking insects at cucumber plants.
\end{abstract}

Keywords: Cucumber, Aphis gossypii, Bemisia tabaci, sulfoximines, flupyradifurone, neonicotinoid

\section{INTRODUCTION}

Cucurbits represent an important part of vegetable production and are considered very important in agricultural crops in Egypt. They are cultivated in wide areas either old lands or newly reclaimed lands. Cucumber, Cucumis sativus L. is one of the most important cucurbitaceous vegetable crops in Egypt, as it is cultivated under different environmental conditions, open fields and greenhouses for local consumption and exportation (Mohamed, 2012).

The cotton aphid, Aphis gossypii Glover (Hemiptera: Aphididae), is hazardous to many agricultural crops worldwide. It is a highly polyphagous pest, feeding on> 320 plant species of 46 families, including Cucurbitaceae, Malvaceae, Solanaceae, and Rutaceae (Blackman and Eastop, 2000; Aheer et al. 2008; Mesbah et al. 20016; and Almasi et al., 2018). Cotton aphids physically damage the plants by directly sucking their phloem sap, which can result in premature leaf drop، wilting, and desiccation of the host plants (Attia and El-Hamaky, 1987). Indirect damages by aphids include the honeydew extractions that substantially impact the photosynthesis rate and plant growth (Kersting et al., 1999), and cause transition of over 76 plant pathogenic viruses (Kim، 2007; Kersting et al., 1999), resulting in significant crop loss (Nazeri et al.2018).

The whitefly, Bemisia tabaci (Genn.) considered one of the most important pests infesting cucumber plants during its three growth stages, seedling, flowering and fruiting. The behavior of this insect makes chemical control difficult i.e. adult feeding; mating and oviposition and larval development occur on the lower surface of the leaves (Coudriet et al., 1985; Mohamed, 2012). The nymphal and adult stages of this pest feed on phloem sap and excrete honeydew that hamper photosynthesis and render fruits unmarketable (Lenteren Van and Noldus, 1984). In addition, B. tabaci can transmit more than 90 types of plant virus (Jorge and Mendoza, 1995; Hunter and Polston, 2001) including the tomato yellow leaf curl virus (Ghanim and Czosnek, 2000), the sweet ptato leaf curl virus (Lotrakul et al., 1998) and the tomato mottle virus (Brown 1994; Heinz 1996; Hunter et al., 1998 and Jones, 2003).

Sulfoximines are a new class of insecticides targeting sap-feeding insects (Babcock et al.,2011and Sparks et al., 2012) including the aphids, whiteflies, hoppers, and lygus (Nawaz et al., 2018; Babcock et al., 2011 and Zhu et al., 2011). Sulfoxaflor is the initial compound in this new sulfoximine insecticide class to be selected for commercial development. Sulfoxaflor is an agonist at insect nicotinic acetylcholine receptors (nAChRs) and functions in a manner distinct from other insecticides acting at nAChRs (Liao et al.,2017; Watson et al., 2017; Sparks et al., 2013). The sulfoximines are also effective against a wide range of sap-feeding insect pests that are resistant to other classes of insecticides, such as neonicotinoids (Zhu et al., 2011; Sparks et al., 2013. Also, sulfoxaflor is reported as being slightly harmful to biological control agents, including Nesidiocoris tenuis (Reuter) (Hemiptera: Miridae), Chrysoperla carnea (Stephens) (Neuroptera: Chrysopidae), and Adalia bipunctata (L.) (Coleoptera: Coccinellidae) (Sparks et al., 2013; Wanumen et al., 2016 and Nawaz et al., 2018,).

Flupyradifurone, is a member of the new class of butenolide insecticides, contains a novel bioactive

DOI: 10.21608 /ASEJAIQJSAE.2019.34334

${ }^{1}$ Plant Protection Research Institute, Etay El-baroud Agric. Res. Station. Agric. Res. Center, Egypt.

Received May 14, 2019, Accepted June 11, 2019 
scaffold as pharmacophore. It is very versatile in terms of application methods to variety of crops, exhibits excellent and fast action against a broad spectrum of sucking pest insects including selected neonicotinoid resistant pest populations such as whiteflies and aphids expressing metabolic resistance mechanisms (Jeschke et al. 2015). The butenolide insecticide flupyradifurone acts selectively on the insect central nervous system (CNS) as a partial agonist of post synaptic $n$ AChRs and binds to the acetylcholine (Ach) binding site (Nauen et al. 2014). Flupyradifurone provides excellent control of many sucking pests resistant to other chemical classes including neonicotinoids, and is thus a new resistance management tool for sustainable pest control. As a modern insecticide and based on the results at manufacturer recommended field-rates, it has an excellent profile concerning human- and environmental safety, safety to bees as well as bumble bees (Smith and Giurcanu 2013; Haas et al. 2014).

The purpose of this study was to determine the efficiency of a new or non-conventional groups of insecticides against the whiteflies, B. tabaci, cotton aphid, Aphis gossypii and their associated predators on cucumber plants at recommended rates, during 2017 and 2018 summer seasons at Nubarya district, El-Beheira Governorate.

\section{MATERIALS AND METHODS}

\section{Insects}

\section{Tested compounds:}

Sulfoxaflor (Closer 24\%, SC) was provided by DowAgro Sciences Co., Ltd. Flupyradifurone (Sivantoprime $20 \%$, SL) was provided by Bayer Crop Science. Clothianidin (Supertox-1 ${ }^{\circledR} 48 \%$, SC) was provided by Jiangs Jiag chemical industry Co. Ltd China. Thiamethoxam (Actara 25\%, WG) provided by Syngenta Company. Acetamiprid (Mospilan 20\%, SP) provided by Nippon Soda Chemical Industry Co. Ltd.

The field trials:
Field experiments were carried out throughout two successive seasons (2017 and 2018) during summer plantation in Nubarya district, El-Beheira Governorate. These experiments were cultivated with cucumber varieties, Cucumis sativus L. (Prince). The experimental site was divided into 24 plots, each plot $1 / 100$ feddan $\left(42 \mathrm{~m}^{2}\right)$. Randomized complete blocks design was used with four replicates for each treatment with the control plots. Field concentrations were $40 \mathrm{ml}, 240 \mathrm{ml}, 1000 \mathrm{ml}$, $60 \mathrm{gm}$ and $50 \mathrm{gm} / 200$ liters per feddan for sulfoxaflor, flupyradifurone, clothianidin, thiamethoxam, and acetamiprid, respectively. The insecticides were sprayed by Knapsack sprayer equipment (CP3). For counting the numbers of whiteflies, B. tabaci (immature stages) and cotton aphid, A. gossypii, samples of 25 leaves (from three different levels of the plants) were collected at random in the morning for both diagonals of the inner square area of each experimental plot. Pre-treatment counts were done in the early morning just before application while post-treatment counts were done on 1, 4, 7and 10 days after treatment. In the same time, sample of 25 cucumber plants were examined and the number of the aphid lion, Chrysoperla carnea, and the lady birds, Coccinella spp. were counted. Counts were done by the lenses in the early morning when flight activity is minimal according to Bulter et al. (1988). Percentages of pest reduction numbers were calculated according to Henderson and Tilton equation (1955) and subjected to analysis of variance (ANOVA) (CoStat Statistical software,1998).

\section{RESULTS AND DISCUSSION}

Gradual reduction percentages of whitefly numbers as a result of insecticide treatments were recorded in both seasons 2017and 2018 (Tables 1and 2). The highest reduction percentages of whitefly were recorded for flupyradifurone and sulfoxaflor where the mean reduction percentages were $97.73 \%$ and $92.43 \%$ at 2017 and $96.75 \%$ and $94.48 \%$ at 2018 , respectively. The least reduction percentages were recorded by acetamiprid where the mean reduction percentages were 69.50 and $79.08 \%$ at 2017 and 2018, respectively.

Table 1. Efficacy of certain treatments against Bemisia tabaci immature stages on cucumber plants at 2017 season

\begin{tabular}{ccccccc}
\hline Tested compounds & Rate $/$ & \multicolumn{5}{c}{ \%Reduction After } \\
\cline { 3 - 7 } & feddan & 1-day & 4-days & 7-days & 10-days & Mean \\
\hline Sulfoxaflor & $40 \mathrm{ml}$ & 79.8 & 92.5 & 98.2 & 99.2 & $92.43 \mathrm{~b}$ \\
Flupyradifurone & $240 \mathrm{ml}$ & 92.8 & 98.4 & 100.0 & 99.7 & $97.73 \mathrm{a}$ \\
Clothianidin & $1000 \mathrm{ml}$ & 80.2 & 91.8 & 90.8 & 89.3 & $88.03 \mathrm{c}$ \\
Thiamethoxam & $60 \mathrm{~g}$ & 78.8 & 84.1 & 91.1 & 86.8 & $85.20 \mathrm{c}$ \\
Acetamiprid & $50 \mathrm{~g}$ & 65.1 & 69.3 & 74.2 & 69.4 & $69.50 \mathrm{~d}$ \\
\hline
\end{tabular}

Means within the same column followed by the same letters are not significantly different according to the $\operatorname{LSD}_{0.05}$. 
Table 2. Efficacy of certain treatments against Bemisia tabaci immature stages on cucumber plants at 2018 season

\begin{tabular}{ccccccc}
\hline Tested compounds & Rate / & \multicolumn{5}{c}{ \%Reduction After } \\
\cline { 3 - 7 } & feddan & 1-day & 4-days & 7-days & 10-days & Mean \\
\hline Sulfoxaflor & $40 \mathrm{ml}$ & 88.9 & 95.4 & 98.1 & 95.5 & $94.48 \mathrm{a}$ \\
Flupyradifurone & $240 \mathrm{ml}$ & 91.2 & 95.8 & 100.0 & 100.0 & $96.75 \mathrm{a}$ \\
Clothianidin & $1000 \mathrm{ml}$ & 88.8 & 94.2 & 100.0 & 98.1 & $95.28 \mathrm{a}$ \\
Thiamethoxam & $60 \mathrm{~g}$ & 76.5 & 90.1 & 89.2 & 88.5 & $86.08 \mathrm{~b}$ \\
Acetamiprid & $50 \mathrm{~g}$ & 68.7 & 82.5 & 84.2 & 80.9 & $79.08 \mathrm{c}$ \\
\hline
\end{tabular}

Means within the same column followed by the same letters are not significantly different according to the $\mathrm{LSD}_{0.05}$.

In this study, field evaluation of some insecticides treatments against aphids on the cucumber plants at 2017 and 2018 seasons was carried out (Tables 3 and 4). In both seasons, the highest reduction percentages were achieved by flupyradifurone and sulfoxaflor treatments, where the mean reduction percentages were $98.33 \%$ and $96.00 \%$ at 2017 and $96.70 \%$ and $94.05 \%$ at 2018, respectively. The least reduction percentages were recorded by acetamiprid treatments where the mean reduction percentages were 64.45 and $73.60 \%$ at 2017 and 2018, respectively.

These results indicate that, neonicotinoids provide excellent control of many sucking pests as B. tabaci (Kuhar et al., 2002), and aphids (Daniels et al. 2009). Flupyradifurone and sulfoxaflor are also effective against a wide range of sap-feeding insect pests that are resistant to other classes of insecticides, including many that are resistant to the neonicotinoids (Zhu et al., 2011;
Sparks et al., 2013; Jeschke et al. 2015; Liao et al. 2017 and Wang et al. 2017).

Data from Tables 5, 6, 7 and 8 indicate the reduction percentages of $C$. carnea and Coccinella spp caused by sulfoxaflor, flupyradifurone, clothianidin, thiamethoxam, and acetamiprid treatments. For $C$. carnea were $22.00,29.95,52.90,46.90$ and $43.08 \%$, respectively at 2017 and $27.88,27.15,46.48,40.96$ and $36.88 \%$, respectively at 2018 . While reduction percentages of Coccinella spp caused by sulfoxaflor, flupyradifurone, clothianidin, thiamethoxam, and acetamiprid were $14.75,14.38,23.40,20.60$ and $21.35 \%$, respectively at 2017 and $12.00,15.78,24.35$, 22.73 and $19.48 \%$, respectively at 2018 . Concerning data, all treatments have moderate toxic effect on natural enemies except sulfoxaflor and flupyradifurone had slightly toxic effect.

Table 3. Efficacy of certain treatments against Aphis gossypii on cucumber plants at 2017 season

\begin{tabular}{ccccccc}
\hline Tested compounds & Rate / & \multicolumn{5}{c}{ \%Reduction After } \\
\cline { 3 - 7 } & feddan & 1-day & 4-days & 7-days & 10-days & Mean \\
\hline Sulfoxaflor & $40 \mathrm{ml}$ & 91.4 & 95.1 & 100.0 & 97.5 & $96.00 \mathrm{ab}$ \\
Flupyradifurone & $240 \mathrm{ml}$ & 95.1 & 98.2 & 100.0 & 100.0 & $98.33 \mathrm{a}$ \\
Clothianidin & $1000 \mathrm{ml}$ & 87.1 & 95.3 & 100.0 & 99.8 & $95.55 \mathrm{ab}$ \\
Thiamethoxam & $60 \mathrm{~g}$ & 82.4 & 90.2 & 93.1 & 90.8 & $89.13 \mathrm{~b}$ \\
Acetamiprid & $50 \mathrm{~g}$ & 72.8 & 64.1 & 66.7 & 54.2 & $64.45 \mathrm{c}$ \\
\hline
\end{tabular}

Means within the same column followed by the same letters are not significantly different according to the LSD 0.05 .

Table 4. Efficacy of certain treatments against Aphis gossypii on cucumber plants at 2018 season

\begin{tabular}{ccccccc}
\hline Tested compounds & Rate $/$ & \multicolumn{5}{c}{ \%Reduction After } \\
\cline { 3 - 7 } & feddan & 1-day & 4-days & 7-days & 10-days & Mean \\
\hline Sulfoxaflor & $40 \mathrm{ml}$ & 89.5 & 96.5 & 95.3 & 94.9 & $94.05 \mathrm{a}$ \\
Flupyradifurone & $240 \mathrm{ml}$ & 88.4 & 98.4 & 100.0 & 100.0 & $96.70 \mathrm{a}$ \\
Clothianidin & $1000 \mathrm{ml}$ & 82.4 & 95.4 & 100.0 & 92.8 & $92.65 \mathrm{a}$ \\
Thiamethoxam & $60 \mathrm{~g}$ & 78.3 & 88.5 & 81.4 & 86.0 & $83.55 \mathrm{~b}$ \\
Acetamiprid & $50 \mathrm{~g}$ & 66.2 & 79.4 & 79.6 & 69.2 & $73.60 \mathrm{c}$ \\
\hline
\end{tabular}

Means within the same column followed by the same letters are not significantly different according to the $\mathrm{LSD}_{0.05}$. 
Table 5. Efficacy of certain treatments against Chrysoperla carnea on cucumber plants at 2017 season

\begin{tabular}{ccccccc}
\hline Tested compounds & Rate $/$ & \multicolumn{5}{c}{ \%Reduction After } \\
\cline { 3 - 7 } & feddan & 1-day & 4-days & 7-days & 10-days & Mean \\
\hline Sulfoxaflor & $40 \mathrm{ml}$ & 22.1 & 26.3 & 20.3 & 19.3 & $22.00 \mathrm{~d}$ \\
Flupyradifurone & $240 \mathrm{ml}$ & 26.4 & 33.3 & 33.3 & 26.8 & $29.95 \mathrm{c}$ \\
Clothianidin & $1000 \mathrm{ml}$ & 52.3 & 71.6 & 45.6 & 42.1 & $52.90 \mathrm{a}$ \\
Thiamethoxam & $60 \mathrm{~g}$ & 45.9 & 55.3 & 45.5 & 40.9 & $46.90 \mathrm{ab}$ \\
Acetamiprid & $50 \mathrm{~g}$ & 42.1 & 46.3 & 44.8 & 39.1 & $43.08 \mathrm{~b}$ \\
\hline
\end{tabular}

Means within the same column followed by the same letters are not significantly different according to the $\mathrm{LSD}_{0.05}$.

Table 6. Efficacy of certain treatments against Chrysoperla carnea on cucumber plants at 2018 season

\begin{tabular}{ccccccc}
\hline Tested compounds & Rate / & \multicolumn{5}{c}{ \%Reduction After } \\
\cline { 3 - 7 } & feddan & 1-day & 4-days & 7-days & 10-days & Mean \\
\hline Sulfoxaflor & $40 \mathrm{ml}$ & 26.2 & 31.5 & 29.5 & 24.3 & $27.88 \mathrm{c}$ \\
Flupyradifurone & $240 \mathrm{ml}$ & 33.3 & 26.5 & 26.5 & 22.3 & $27.15 \mathrm{c}$ \\
Clothianidin & $1000 \mathrm{ml}$ & 55.2 & 47.9 & 44.4 & 38.4 & $46.48 \mathrm{a}$ \\
Thiamethoxam & $60 \mathrm{~g}$ & 36.5 & 53.2 & 47.1 & 27.1 & $40.96 \mathrm{ab}$ \\
Acetamiprid & $50 \mathrm{~g}$ & 35.2 & 44.3 & 38.4 & 29.6 & $36.88 \mathrm{~b}$ \\
\hline
\end{tabular}

Means within the same column followed by the same letters are not significantly different according to the $\mathrm{LSD}_{0.05}$.

Table 7. Efficacy of certain treatments against Coccinella spp on cucumber plants at 2017 season

\begin{tabular}{ccccccc}
\hline Tested compounds & Rate $/$ & \multicolumn{5}{c}{ \%Reduction After } \\
\cline { 3 - 7 } & feddan & 1-day & 4-days & 7-days & 10-days & Mean \\
\hline Sulfoxaflor & $40 \mathrm{ml}$ & 12.8 & 15.0 & 16.1 & 15.1 & $14.75 \mathrm{~b}$ \\
Flupyradifurone & $240 \mathrm{ml}$ & 13.5 & 15.0 & 17.1 & 11.9 & $14.38 \mathrm{~b}$ \\
Clothianidin & $1000 \mathrm{ml}$ & 27.3 & 25.2 & 26.1 & 15.0 & $23.40 \mathrm{a}$ \\
Thiamethoxam & $60 \mathrm{~g}$ & 19.8 & 27.3 & 16.7 & 18.6 & $20.60 \mathrm{a}$ \\
Acetamiprid & $50 \mathrm{~g}$ & 18.3 & 25.4 & 25.0 & 16.7 & $21.35 \mathrm{a}$ \\
\hline
\end{tabular}

Means within the same column followed by the same letters are not significantly different according to the $\operatorname{LSD}_{0.05}$.

Table 8. Efficacy of certain treatments against Coccinella spp on cucumber plants at 2018 season

\begin{tabular}{ccccccc}
\hline Tested compounds & Rate / & \multicolumn{5}{c}{ \%Reduction After } \\
\cline { 3 - 7 } & feddan & 1-day & 4-days & 7-days & 10-days & Mean \\
\hline Sulfoxaflor & $40 \mathrm{ml}$ & 11.3 & 13.8 & 12.5 & 10.4 & $12.00 \mathrm{c}$ \\
Flupyradifurone & $240 \mathrm{ml}$ & 14.1 & 16.5 & 17.3 & 15.2 & $15.78 \mathrm{bc}$ \\
Clothianidin & $1000 \mathrm{ml}$ & 20.0 & 27.4 & 33.2 & 16.8 & $24.35 \mathrm{a}$ \\
Thiamethoxam & $60 \mathrm{~g}$ & 16.5 & 22.2 & 27.1 & 25.1 & $22.73 \mathrm{a}$ \\
Acetamiprid & $50 \mathrm{~g}$ & 20.2 & 22.2 & 16.0 & 19.5 & $19.48 \mathrm{ab}$ \\
\hline
\end{tabular}

Means within the same column followed by the same letters are not significantly different according to the $\mathrm{LSD}_{0.05}$.

Our results were comparable with Sparks et al., 2013; Wanumen et al., 2016 and Nawaz et al., 2018, who reported that, sulfoxaflor is slightly harmful to biological control agents, including, C. carnea (Neuroptera: Chrysopidae), and C. bipunctata (Coleoptera: Coccinellidae). Flupyradifurone has an excellent profile concerning human- and environmental safety (Smith and Giurcanu 2013; Haas et al. 2014 and Jeschke et al. 2015).

It can be concluded that, sulfoxaflor and flupyradifurone are the preferred insecticides with less toxicity to the natural enemies and can be used to control sucking insects in IPM programs.

\section{REFERENCES}

Aheer, G. M., A. Ali and M. Munir. 2008. Abiotic factors effect on population fluctuation of alate aphids in wheat. $\mathrm{J}$. Agric. Res. 46: 367-371.

Almasia A., A. Rasekha, M. Esfandiaria, M. Seyahooeib and M. Ziaeea. 2018. The prospect of using sub-lethal imidacloprid or pirimicarb and a parasitoid wasp, Lysiphlebus fabarum, simultaneously, to control Aphis gossypii on cucumber plants. J. Asia-Pacific Entomol. 21: 161-167.

Attia, A.A., and M.A. El-Hamaky. 1987. The biology of the cotton aphid Aphis gossypii Glover in Egypt (Homoptera: aphididae). Bull. Entomol. Soc. Egypt. 85: 359-371. 
Babcock, J.M., C.B. Gerwick, J.X. Huang, M.R. Loso, G. Nakamura, S.P. Nolting, R.B. Rogers, T.C. Sparks, J. Thomas, G.B. Watson and Y. Zhu. 2011. Biological characterization of sulfoxaflor, a novel insecticide. Pest. Manag. Sci. 67: 328-334.

Blackman, R.L. and V.F. Eastop. 2000. Aphids on the world's crops: An identification and information guide, Second ed. John Wileyand Sons, London, UK (481 pp).

Brown, J. K. 1994. Current status of Bemisia tabaci as a plant pest and virus vector in agro ecosystems worldwide. FAO Plant Protection Bulletin. 42 (2): 1-32.

Butler, G. D., D. L. Coudriet and T. V. Hennebery. 1988. Toxicity and repellance of soybeans and cottonseed oils to the sweet potato whitefly and the aphids on cotton in greenhouse studies. Southwest, Entomol. 13: 81-96.

CoStat Statistical Software. 1998. Microcomputer program analysis version 6.400, CoHort Software, Berkeley, CA.

Coudriet, D.L., N. Prabhaker, A. N. Kishaba and D. E. Meyerdirk. 1985. Variation in developmental rate on different hosts and overwintering of the sweetpotato whitefly, Bemisia tabaci (Homoptera:Aleyrodidae). J. Econ. Entomol. 14: 516-519.

Daniels, M., J. S. Bale, H. J. Newbury, R. J. Lind and J. Pritchard.2009. A sublethal dose of thiamethoxam causes a reduction in xylem feeding by the bird cherry-oat aphid (Rhopalosiphum padi), which is associated with dehydration and reduced performance. J. Insect Physiol. 55: 758-765.

Ghanim, M. and H. Czosnek. 2000. Tomato yellow leaf curl geminvirus (TYLCV-Ls) is transmitted among whiteflies (Bemisia tabaci) in a sex-related manner. J. Virol.74: 4738-4745.

Haas, M. K., P. Jeschke, R. Velten and R. Nauen. 2014. Sivanto ${ }^{\text {TM: }}$ a novel insecticide with a sustainable profile. 13th IUPAC International Congress of Pesticide Chemistry, ORGN-452, San Francisco, USA, August 1014.

Heinz, K. 1996. Predators and parasitoids as biological control agents of Bemisia in greenhouse. In: Gerling D, Mayer RT, Editors. Bemisia, 1995: Taxonomy, Biology, Damage Control and Management. pp. 439-449. Intercept Ltd.

Henderson, C. F. and E. W. Tilton .1955. Test with acaricides against the brown wheat mite. J. Econ. Entomol. 48: 157161.

Hunter, W. B. and J. E. Polston. 2001. Development of a continuous whitefly cell line [Homoptera: Aleyrodidae) Bemisia tabaci (Gennadius)] for the study of Begomovirus. J. Invert. Pathol. 77: 33-36.

Hunter, W. B., E. Hiebert, S. E. Webb, J. H. Tsai and J. E. Polston. 1998. Location of geminivruses in the whitefly, Bemisia tabaci (Homoptera: Aleyrodidae). Plant Dis. 82: 1147-1151.
Jeschke, P., R. Nauen, O. Gutbrod, M. E. Beck, S. Matthiesen, M. Haas and R. Velten. 2015. Flupyradifurone (Sivanto ${ }^{\mathrm{TM}}$ ) and its novel butenolide pharmacophore: Structural considerations. Pestic. Biochem. and Physiol. 121: 31-38.

Jones, D. 2003. Plant viruses transmitted by whiteflies. Europ. J. Plan. Path. 109: 197-221.

Jorge, S. and O. Mendoza. 1995. Biology of the sweet potato whitefly (Homoptera: Aleyrodidae) on tomato. Flor. Entomol. 78: 154- 160.

Kersting, U., S. Satar and N. Uygun. 1999. Effect of temperature on development rate and fecundity of apterous Aphis gossypii Glover (Homoptera: Aphididae) reared on Gossypium hirsutum L. J. Appl. Entomol. 123: 23-27.

Kim, J.J. 2007. Influence of Lecanicillium attenuatum on the development and reproduction of the cotton aphid, Aphis gossypii. Bio Control. 52: 789-799.

Kuhar, P. T., L. J. Stivers-Young, M. P. Hoffmann and A. G. Taylor. 2002. Control of corn flea beetle and Stewart's wilt in sweet corn with imidacloprid and thiamethoxam seed treatments. Crop Protection. 21:25-31.

Lenteren Van, J.C. and L.P.J.J. Noldus. 1984. Whitefly-plant relationship: behavioural and ecological aspects. In: Gerling, D. (Ed.), Whiteflies: Their Bionomics Pest Status and Management. Published Intercept Ltd., p. 348.

Liao, Z., K. Mao, E. Ali, X. Zhang, H. Wan and J. Li. 2017. Temporal variability and resistance correlation of sulfoxaflor susceptibility among Chinese populations of the brown planthopper Nilaparvata lugens (Stål). Crop Protection. 102: 141-146.

Lotrakul, P., R. A. Valverde, C. A. Clark J. Sim and D. L. Torre. 1998. Detection of geminivirus infecting sweet potato in the United States. Plant dis. 82: 1253-1257.

Mesbah, H.A., N.A. Elsayed, N.A. Hassan and S. A. Ahmed. 2016. Efficiency of Certain Evaluated Pesticides and Phytochemicals on the Inspected Aphids (A. gossypii) on Growing Cucumber Plants in Greenhouse and Market. Alex. Sci . Exch. J. 37: 95-101.

Mohamed M.A. 2012. Impact of planting dates, spaces and varieties on infestation of cucumber plants with whitefly, Bemisia tabaci (Genn.). J. of Basic \& Appl. Zoo. 65: 1720.

Nauen, R., P. Jeschke, R. Velten, M.E. Beck, U. EbbinghausKintscher and W. Thielert. 2014. Flupyradifurone: a brief profile of a new butenolide insecticide. Pest Manag. Sci. 10:1002-3932.

Nawaz M., M. Hafeez, J. I. Mabubu, F. U. Dawar, X. Li, M. M. Khan, H. Hua and W. Cai. 2018. Transcriptomic analysis of differentially expressed genes and related pathways in Harmonia axyridis after sulfoxaflor exposure. Inter. J. of Bio. Macro. 119: 157-165.

Nazeri, M, H. Allahyari and H. Goldansaz. 2018. Reciprocal indirect interactions between Tetranychus urticae and Aphis gossypii mediated by cucumber plant. J. AsiaPacific Entomol. 21: 843-851. 
Smith, H.G. and M.C. Giurcanu. 2013. Residual effects of new insecticides on egg and nymph densities of Bemisia tabaci (Hemiptera: Aleyrodidae). Flo Entomol. 96: 504511.

Sparks, T. C., G. B. Watson, M. R. Loso, C Gengm J. M. Babcock and J. D. Thomas. 2013. Sulfoxaflor and the sulfoximine insecticides: Chemistry, mode of action and basis for efficacy on resistant insects. Pestic. Biochem. and Physio. 107: 1-7.

Sparks, T.C., M.R. Loso, G.B. Watson, J.M. Babcock, V.J. Kramer, Y. Zhu, B.M. Nugent and J.D. Thomas. 2012. Sulfoxaflor, in: W. Kramer, U. Schirmer, P. Jeschke, M. Witschel (Eds.), Modern Crop Protection Compounds, Insecticides, second ed., vol. 3, Wiley-VCH, Weinheim, GR. pp. 1226-1237.

Wang A. W., S. Wang, G. Han, Y. Du and J. Wang. 2017. Lack of cross-resistance between neonicotinoids and sulfoxaflor in field strains of Q-biotype of whitefly,
Bemisia tabaci, from eastern China. Pestic. Biochem. and Physio.136: 46-51.

Wanumen, A.C., I. Sánchez-Ramos, E. Viñuela, P. Medina and Á. Adán. 2016. Impact of feeding on contaminated prey on the life parameters of Nesidiocoris tenuis (Hemiptera: Miridae) adults, J. Insect Sci. 16: 103.

Watson, G.B., M.B. Olson, K.W. Beavers, M.R. Loso and T.C. Sparks. 2017. Characterization of a nicotinic acetylcholine receptor binding site for sulfoxaflor, a new sulfoximine insecticide for the control of sap-feeding insect pests. Pestic. Biochem. Physio. 143: 90-94.

Zhu, Y., M.R. Loso, G.B. Watson, T.C. Sparks, R.B. Rogers, J.X. Huang, B.C. Gerwick, J.M. Babcock, D. Kelley, V.B. Hegde, B.M. Nugent, J.M. Renga, I. Denholm, K. Gorman, G.J. Deboer, J. Hasler, T. Meade and J.D. Thomas. 2011. Discovery and characterization of sulfoxaflor, a novel insecticide targeting sap-feeding pests. J. Agric. Food Chem. 59: 2950-2957.

\section{الملخص العربي}

الكفاعة الحقلية لبعض المبيدات الحديثة ضد بعض الحشرات الثاقبة الماصة على الخيار.

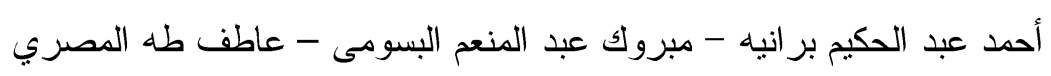

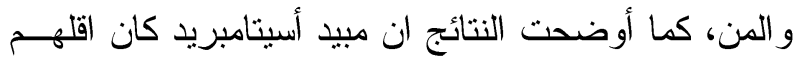

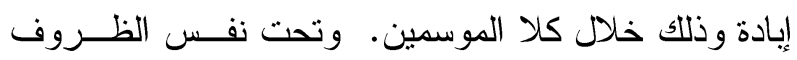

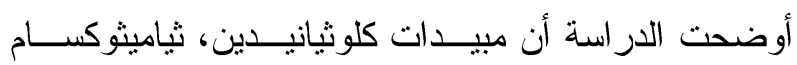

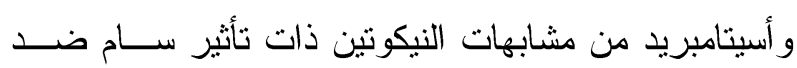

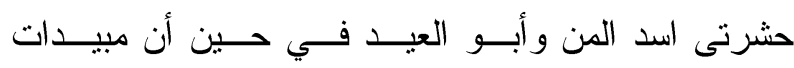

السلفوكسافلور، الفلوبيز اديفورون كان تأثير هما الضار قليل النيل

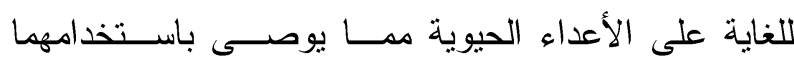

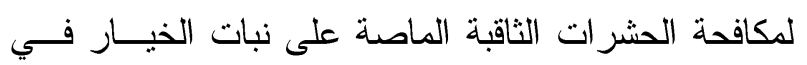

إطار برامج المكافحة المتكاملة.

أجرى هذا البحث لتقدير الكفاءة الحقلية لمبيدين جديدين

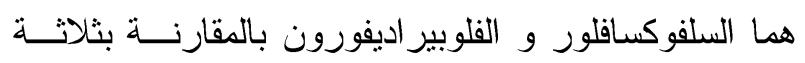

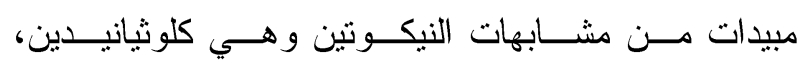
ثباميثوكسام و أسيتامبريد وذلك رشا بالجرعات الحقلية ضد

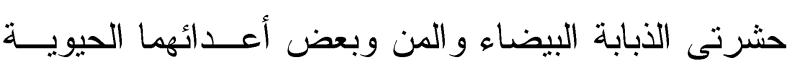

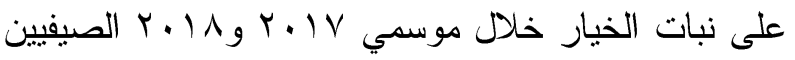

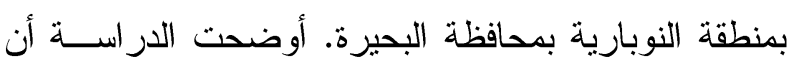
مبيدى السلفوكسافلور و الفلوبيراديفورون أكثر كفاءة مـن بـن كل المبيدات المستخدمة ضد حشـــتى الذبابــة البيضــــاء 